the number of Earth stations in the Intelsat network had grown to twenty-two, compared with fourteen at the end of the previous year. Voice circuits on permancnt lease amounted to 941 by the end of 1968 , thus loading almost to full capacity the Early Bird and Intelsat II satellites then in service. Further growth depends on the Intelsat III satellites, the first two of which, over the Atlantic and the Pacific, have each added 1,200 circuits to the capacity of Intelsat. The disappointment of the failure of the first launch of an Intelsat III satellite just before the Olympic Games in Tokyo has evidently not left too deep a mark. Comsat managed to sell 666 hours of television time during 1968, much of it during the Olympic Games, and thus multiplied by three its previous record for television.

Comsat is plainly bursting with new plans, almost as if the $\$ 130$ million of shareholders' money still held in short-term investments is burning a hole in its pocket. The scheme which it prepared in 1967 for a domestic communications system within the United States, thirty-five ground stations strong, could obviously use up a great deal of capital. So could the stations in Alaska and South America for which Comsat has already submitted applications to the Federal Communications Commission. Much will depend on the outcome of the new administration's study of the report of the task force set by President Johnson to study the future pattern of domestic telecommunications, but it is hard to see how any government would be able to deny some room for growth to this energetic child which is, after all, the product of an earlier compromise with Congress. In terms of simple money, Comsat has in any case performed respectably enough for a growth industry, although money in the bank still provides $\$ 8.5$ million of revenue compared with $\$ 30.5$ million from operations. The surplus on the operating budget is comparatively small-less than $\$ 1$ million or just about 3 per cent, so that the money in the bank is a necessary way of keeping the shareholders happy. Whether the countries which belong to Intelsat are equally happy with a state of affairs in which Comsat enters communal property on its books under the simple heading "assets", and then pays federal income tax on the investment, is another matter which may receive some attention between now and November 18.

\section{STUDENT OPINIONS}

\section{Harvard in Waiting}

from a Correspondent recently in Cambridge, Mass.

HARVARD awards about twenty per cent of its bachelor degrees each year in science, yet science students were a smaller percentage of the political activists who precipitated the recent crisis. The political inactivity of scientists is of course legendary, but it does now seem that the behaviour which is expected of them, still superficially in evidence, may be wearing thin. To be sure, they work harder than other students, tend to be less social and, in general, accept the values of scientific and scholarly achievement, but this is the surface and it is thin. Although few science students are politically active-but a small group of mathematicians is identified as members of Progressive Labour, the left wing of SDS-they seem no longer to be politically inert. Rather, two strong and conflicting trends emerged from my interviews with them. One was expressed by a student when he said: "I think these last few weeks will push people into rather than out of science. This has been a harrowing experience. People seek stability and science is more stable."

'This student, as well as others, spoke of the order in science which has often accounted for the science student viewing many political disorders as transient and outside his higher goal of the search for truth. That this vision still retains its power is shown by the fact that, during the course of the strike and the general upheaval, not one of 280 biochemistry undergraduates missed his tutorial. But for many, this stability now represents isolation, and the isolation comes about largely through the demands of long hours in the laboratory. Typical responses were "Lab. courses are destructive to undergraduate life. I always wonder whether I shouldn't be doing something else when I'm in lab." or "Labs. turn me off. I like the thinking part of Chemistry . . the thought of a lab. for life . . . very depressing."

Undoubtedly the complaints about laboratory work are not new. Although desire for more social life and for more involvement was always present, the laboratory offered itself as a sanctuary which overrode those considerations. Now one hears the phrase "social relevance". How does one justify the time spent in the laboratory ? The upswing in enrolment in biochemical sciences reflects the attempt to link chemistry with doing something for mankind. In the post-Sputnik phase, science was its own justification. As one young man said: "During that period in my high school, if you were smart, you were smart in science". But now he, like many others, is torn.

The science student is being affected by the premium on individuality and "doing one's thing". As a non-active SDS sympathizer said somewhat wistfully, "The burden of strikes falls unevenly on science and non-science students". The scientist is faced with the new burden of guilt if he opts out of the moderates' strikes following police busts. But beyond that he, as an undergraduate, is forced to face the conflict that arises between his work and what it means to others.

The Harvard bust seems to have forced an early maturation on its science population. 'The two themes, "the holiness" of the laboratories and the drive for social relevance, are not resolved but remain in conflict.

\section{AWARDS}

\section{Lawrence Memorial Award}

The Ernest Orlando Lawrence Memorial Award for 1969 has been presented by the US Atomic Energy Commission to the following: $\operatorname{Dr}$ G. F. Chew, head, theoretical physics, Lawrence Radiation Laboratory, Berkeley, and professor, University of California; Dr D. T. Cromer, leader, Crystal Chemistry Section, Plutonium Physical Metallurgy Group, Los Alamos Scientific Laboratory, Los Alamos, New Mexico; Dr E. M. Gelbard, consultant, Reactor Theory Department, Bettis Laboratory, Westinghouse Electric Company, Pittsburgh; $\operatorname{Dr} F$. Newton Hayes, lcader, Molecular Radiobiology Section, Biomedical Research Group, Los Alamos Scientific Laboratory: $I_{r}, J . H$. Nuckolls, associate leader of "A" Division, Lawrence Radiation Laboratory, Livermore, California. The award consists of a citation, a medal and $\$ 5.000$. 